\title{
The investigation of the presence of bovine herpesvirus type 4 (BoHV-4) in cows with metritis in a dairy herd
}

\author{
Seval BILGE-DAGALP ${ }^{1}$, Elvin GUNGOR ${ }^{1}$, Ayșe Başak DEMIR ${ }^{1}$, Dilek PINAR-MUZ ${ }^{2}$, \\ Volkan YILMAZ ${ }^{3}$, Tuba Çigdem OGUZOGLU ${ }^{1}$, Veysel Soydal ATASEVEN ${ }^{2}$, Feray ALKAN ${ }^{1}$ \\ ${ }^{1}$ Depertment of Virology, Faculty of Veterinary Medicine, University of Ankara, Ankara; ${ }^{2}$ Depertment of Virology, Faculty of \\ Veterinary Medicine, University of Mustafa Kemal, Hatay; ${ }^{3}$ Depertment of Virology, Faculty of Veterinary Medicine University of \\ Kafkas, Kars- Turkey.
}

Summary: To investigate the occurrence of bovine herpesvirus type 4 (BoHV-4) infection in a dairy herd including cows with metritis, various methods were used for the diagnosis BoHV-4 in vaginal discharge samples. Blood serum samples were obtained from 368 cows for serodiagnosis of BoHV-4 infection. Of 368 serum samples, 256 (69.6\%) were found positive for BoHV4 specific antibodies. For the virological study, vaginal discharge samples of 55 cows with metritis were used and tested for BoHV-4 using polymerase chain reaction (PCR), virus isolation and immunofluorescence techniques. Twenty-nine percent (16/55) of the vaginal discharge samples obtained from cows with metritis were found positive for BoHV-4 DNA by PCR. In this study, the presence of BoHV-4 was determined in cows with metritis in post-partum period in a dairy herd.

Key words: Antibody, bovine herpesvirus type 4, metritis, polymerase chain reaction, sequence analysis.

\section{Bir süt sığırcılığı işletmesinde metritisli ineklerde BoHV-4 ün varlığının araştırılması}

Özet: Metritis olgularının gözlendiği bir sütçü sığır sürüsünde, örneklenen vajinal svaplarda farklı tanı yöntemleriyle BoHV-4 infeksiyonunun varlığı araştırıldı. BoHV-4 ün serolojik tanısı amacıyla 169 adedi metritis semptomları gösteren, 199 adedi ise metritisli hayvanlarla birlikte barındırılan sağlıklı görünümlü hayvanlar olmak üzere toplam 368 adet sığırdan kan serum örneği alınd. Virolojik kontrol amaciyla, metritisli 55 adet inekten alınan vajinal svap örnekleri polimeraz zincir reaksiyonu, virus izolasyonu ve immunfloresan tekniği ile BoHV-4 yönünden araştırıldı. 368 serum örneğinin 256 adedi (\%69.6) BoHV-4 spesifik antikorları yönünden pozitif bulundu. Seropozitiflik oranları, metritisli ve metritisli hayvanlarla birlikte barındırılan sağlıklı görünümlü hayvanlarda sırasıyla, \%69.8 ve \%69 olarak tespit edildi. Metritisli hayvanlardan alınan vajinal svap örneklerinin \%29 (16/55)'unun BoHV-4 DNA'sı yönünden PCR tekniği ile pozitif olduğu saptandı. Bu çalışmada, bir süt sığırcılığı işletmesinde bulunan doğum sonrası dönemdeki metritis problemli ineklerde BoHV-4 ün varlığı belirlenmiştir.

Anahtar sözcükler: Antikor, bovine herpesvirus tip 4, dizin analizi, metritis, polimeraz zincir reaksiyonu.

\section{Introduction}

Bovine herpesvirus type 4 (BoHV-4) belongs to the family Herpesviridae, subfamily Gammaherpesviridae and species Rhadinovirus. BoHV-4 has no close biological and virological relationship to other known herpes viruses of the family Bovidae $(1,16)$.

The virus has been identified in the respiratory tracts of infected animals in cases of vulvovaginitis, endometritis, mastitis, abortion and also from apparently healthy cattle $(2,4,7,11,12,19)$. The role of BoHV-4 in infections occured the respiratory and genital tract has been studied by several researchers and the virus has been reported to be responsible for post-partum and chronic metritis problems alone or with other pathogens $(12,18)$. Like other herpesviruses, BoHV-4 have been persistently infected cattle and latent virus can be reactivated by glycocorticoid treatment and other stress factors (5). The latency of BoHV-4 can establish in lymphoid tissues and a prolonged viremia associated with the mononuclear cells (15). Recently, BoHV-4 were isolated from three vaginal discharge from cows with post-partum metritis where some cows had BoHV-4 spesific neutralizing antibodies (14). This persistent infection is also characterized by constant presence of circulating antibodies. The antibodies against herpesviruses are not fully protective against reinfections (15). Unknown natural stimuli are also able to induce reactivation since infectious virus infrequently recovered from latently infected animals (5). One natural stimulus could be parturation. Cows infected at various stages of gestation showed post-partum metritis (18). Post-partum metritis is often associated with a prolonged excretion of BoHV-4 for several weeks to months $(12,18)$.

In the present study, it is aimed to investigate the presence of BoHV-4 infection in cows with metritis in post-partum period. In addition, the diagnostic values of 
different techniques used for the BoHV-4 detection in vaginal discharge samples was compared.

\section{Materials and Methods}

Herd history and clinical materials: In a dairy herd including 800 milking cows, located in the Marmara district of Turkey, an increase in the post-partum metritis, despite the antibiotic treatment was observed. A combined conventional vaccine including BoHV-1, Bovine Viral Diarrhea Virus (BVDV), Parainfluenza Virus 3 (PIV-3), Bovine Respiratory Syncitial Virus (BRSV) and Haemophilus somnus (Virashild somnus, Novartis, USA) had been used in this dairy herd for 7 years.

Blood serum samples were obtained from 368 cows for serodiagnosis of BoHV-4 infection with enzymelinked immunosorbent assay (ELISA). Of these blood samples 169 were collected from cows showing symptoms of post-partum metritis, 199 of them were collected from clinically healthy cows that were housed together with the cows with post-partum metritis. For the virological study, vaginal discharges samples from 55 cows with metritis were used and tested for BoHV-4 using PCR, VI and IFA techniques.

Blood samples were collected directly into blood tubes with silicon and centrifuged at $1500 \mathrm{~g}$ for 10 minutes to separate the serum which was then stored at $20^{\circ} \mathrm{C}$ until use. Vaginal discharge samples were vortexed and then centrifuged at $1500 \mathrm{~g}$ for 10 minutes. The samples were filtrated and then stored at $-80^{\circ} \mathrm{C}$.

Cell culture and virus: Bovine turbinatae (BT) cell culture was used for propagation of BoHV-4 DN-599 strain, VI and direct IFA techniques. BT cells were grown in Dulbecco's Minimal Essential medium (DMEM) (Gibco, Gibco Laboratories, USA) supplemented with 5\% foetal calf serum (Gibco, Gibco Laboratories, USA), and antibiotics (100 Units Penicilline-G and $0.1 \mathrm{mg}$ dihydro-streptomycin/ml). BoHV-4 DN-599 strain was used as control viruses for PCR and IFA techniques. Reference virus strain was kindly provided by Dr.G.J.Wellenberg (Lelystad, Netherlands).

Indirect ELISA: A commercial indirect ELISA (BioK 066, BioX, Belgium) used for the detection of antibodies against the BoHV-4 was carried out according to the guidelines of the manufacturer.

VI technique: Vaginal discharge samples were inoculated $(100 \mu \mathrm{l})$ onto the BT monolayer. The monolayers were incubated at $37^{\circ} \mathrm{C}$ in an atmosphere with $5 \% \mathrm{CO}_{2}$ and controlled daily for appearence of cytopathic effect (CPE). The monolayers were passaged at weekly intervals for a total of three passages. The supernatants of all cell culture were examined for BoHV4 virus by direct immunofluorescence technique.

IFA technique: IFA technique was applied as described by Nettleton et al (13). Briefly, the supernatants of cell cultures were individually inoculated onto the BT monolayer cultures grown in 24 well plates. At the end of $3 \mathrm{rd}$ day of incubation, the cell cultures were fixed with formol for 10 minutes and stained by using fluorescein-isothiocyanate (FITC) conjugate (Bio028, BioX, Belqium). The results were read by an immunofluorescence microscope (Nikon, Japan). BoHV4 strain DN-599 and non-inoculated BT cells served as positive and negative controls, respectively.

DNA extraction and PCR technique: DNA extractions from vaginal discharge samples were carried out described by Sambrook et al. (17). For detection of BoHV-4 genome a $\mathrm{gB}$ specific $\mathrm{PCR}$ as describe elsewhere (8) was used. The primer pair (B1:5'CCCTTCTTTACCACCACCTACA3') and (B2:5'TGCCATAGCAGAGAAAC AATGA-3') produced a 615 bp fragment.

The detection of BoHV-4 DNA was performed with the use of the BoHV $-4 \mathrm{gB}$ as described by Wellenberg et al (20) with some modifications. Briefly, $3 \mu 1$ of DNA was subjected to thermocycling in a $30 \mu$ reaction mixture. The reaction mix contained $2.5 \mathrm{U}$ Taq Polymerase, $3.5 \mathrm{mM}$ dNTP mix, each primers 10 pmol, $1.5 \mathrm{mM} \mathrm{MgCl}_{2}, 1 \mathrm{X}$ PCR buffer and 6\% DMSO. Thermal cycling conditions were $6 \mathrm{~min}$ at $96^{\circ} \mathrm{C}$ followed by 40 cycles of $56^{\circ} \mathrm{C} 45 \mathrm{sec}, 72^{\circ} \mathrm{C} 2 \mathrm{~min}$, and $95^{\circ} \mathrm{C} 1 \mathrm{~min}$, followed by a final $10 \mathrm{~min}$ extension at $72^{\circ} \mathrm{C}$ for both primer sets. From the final reaction, 3-5 $\mu$ l the amplified PCR products was analyzed by $1 \%$ agarose gel containing ethidium bromide. The gels were read for specific size bands by UV transillumination.

Sequence analysis: The amplified gB PCR products were purified with a kit (Roche, Germany). Nucleotide sequences of the amplified products were detected with in Beckman Coulter CEQ8000 Genetic Analysis system. The sequence data were then subjected to multiple alignment and phylogenetic analysis using MegAlign of the DNAStar Lasergene v7.0 software. The sequence comparisons were obtained for each isolate versus that of BoHV-4 gB segment sequence obtained from the GenBank.

\section{Results}

ELISA: Out of 368 blood sera tested, 256 (69.6\%) showed BoHV-4 antibody by ELISA. Seventy percent of samples (118/169) obtained from cows with post-partum metritis, and $69 \%$ of the samples (138/199) from clinically healthy cattle housed together with the cows with post-partum metritis had antibody against BoHV-4. Serological results of these cows positive to BoHV-4 were also given by Bilge-Dağalp et al (3).

VI and IFA technique: While BoHV-4 has been isolated from 7 (12.7\%) of 55 vaginal discharge samples, $21.8 \%(12 / 55)$ of tested samples were found positive by 

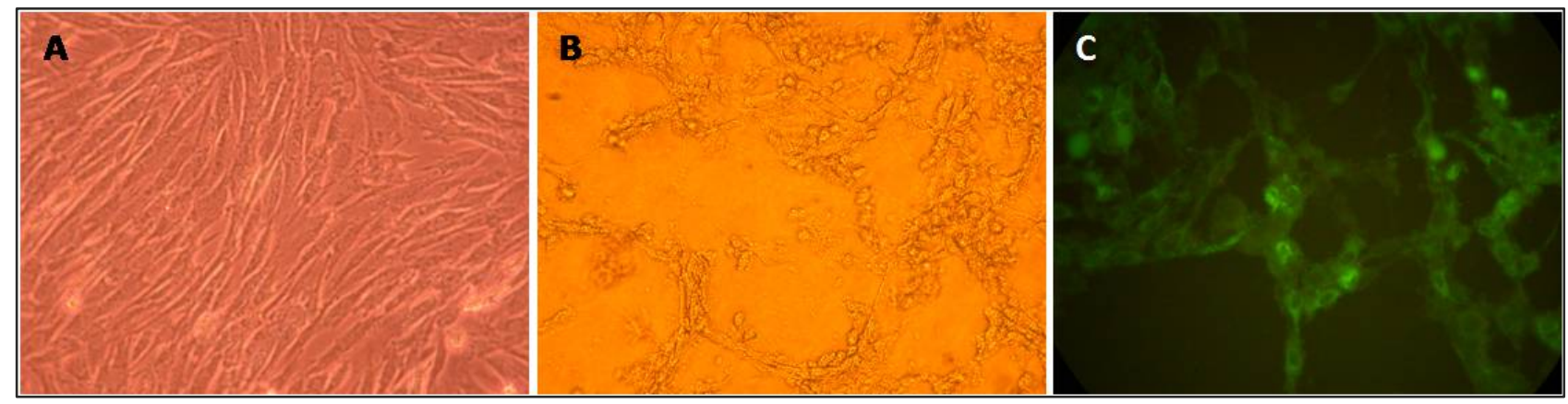

Figure 1. A. Cell control (Bovine Turbinata) X 400, B. The morphological changes of the field isolate K.339 in cell culture (2th passage) X $400\left(4^{\text {th }}\right.$ day $)$ C. The field isolate K.339 in immunofluorescent test X 800.

Şekil 1. A. Hücre kontrol (Bovine turbinate) X 400, B. Saha izolat1 K.339 un (2. pasaj aşamasında) hücre kültüründe oluşturduğu morfolojik değişimler (CPE) X400 (4. gün), C. Saha izolatı K.339 un immunfluoresan testi görüntüsü X800.

IFA technique (Table 1). CPE induced by a BoHV-4 field strains on BT cell line were shown in Figure 1.B. The isolates were identified by PCR and IFA technique. The appearance of BoHV-4 field strains using IFA technique was also given in Figure 1.C.

Table 1. The individual data of animals detected positive for BoHV-4 using PCR

Tablo 1. PCR ile BoHV-4 pozitif olarak saptanan hayvanların bireysel verileri

\begin{tabular}{cccccc}
\hline Animal no & Age & BoHV-4 Ab & gB PCR & VI & IFA \\
\hline K67 & 4 & - & + & + & + \\
K68 & 2 & + & + & - & - \\
K72 & 3 & + & + & + & + \\
K73 & 4 & - & + & - & - \\
K74 & 8 & + & + & - & - \\
K2 & 6 & + & + & - & - \\
K8 & 2 & + & + & - & + \\
K15 & 6 & + & + & - & + \\
K20 & 5 & - & + & + & + \\
K22 & 2 & + & + & + & + \\
K24 & 2 & + & + & + & + \\
K255 & 3 & + & + & - & + \\
K288 & 3 & + & + & - & + \\
K339 & 2 & + & + & + & + \\
K79 & 2 & + & + & - & + \\
K40 & 4 & + & + & + & + \\
Total & & 13 & 16 & 7 & 12 \\
\hline
\end{tabular}

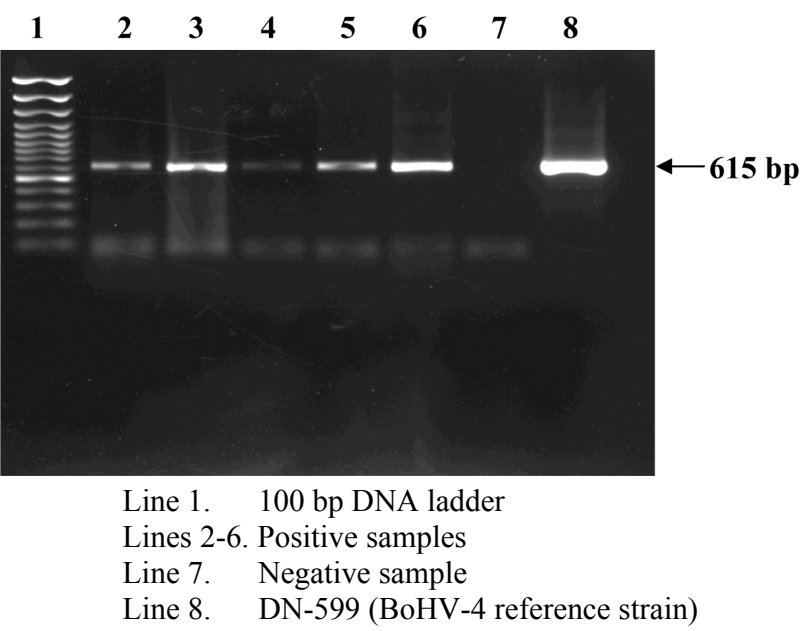

Figure 2. The result of BoHV-4 gB PCR in vaginal discharge samples.

Şekil 2. Vajinal svap örneklerinin BoHV-4 gB PCR sonuçları.

PCR: The amplification of BoHV-4 specific $615 \mathrm{bp}$ fragment from DNA of test samples and positive control virus BoHV-4 DN-599 were described as positive reaction. Out of vaginal discharge samples $29.1 \%(16 / 55)$ were found to be positive for BoHV-4 (Table 1).

Sequence and phylogenetic analysis: K-339 virus isolate was amplified with primer pairs designed for a $615 \mathrm{bp}$ region of the $\mathrm{B}$ gene (Figure 2). The sequences of isolates K-339 is available in Genbank, accession number EU055543. The sequences compared in this paper have

Table 2. An identity/percentage comparison between an isolate (K.339) sequence and published BHV-4 sequences Tablo 2. BoHV-4 K-339 izolatının GenBankasında yeralan diğer dizinlerinin karşılaştırılması

\begin{tabular}{cccccccc}
\hline & K339 & AJ617687 & AJ609274 & AJ617688 & Z15044 & AF318573 & DN599 \\
\hline K339 & ID & 0,994 & 0,994 & 0,994 & 0,992 & 0,992 & 0,990 \\
AJ617687 & 0,994 & ID & 1,000 & 1,000 & 0,998 & 0,998 & 0,996 \\
AJ609274 & 0,994 & 1,000 & ID & 1,000 & 0,998 & 0,998 & 0,996 \\
AJ617688 & 0,994 & 1,000 & 1,000 & ID & 0,998 & 0,998 & 0,996 \\
Z15044 & 0,992 & 0,998 & 0,998 & 0,998 & ID & 1,000 & 0,998 \\
AF318573 & 0,992 & 0,998 & 0,998 & 0,998 & 1,000 & ID & 0,998 \\
DN599 & 0,990 & 0,996 & 0,996 & 0,996 & 0,998 & 0,998 & ID \\
\hline
\end{tabular}


been submitted to GenBank, with accession numbers AJ617688 (UK), AJ609274 (UK), AJ617687 (UK), AF318573 (Mainland Europe), Z15044 (Mainland Europe) and DN-599 (The reference strain of BoHV-4) as indicated in Table 2, Figure 3.

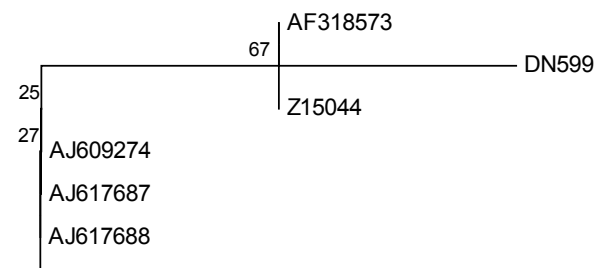

\section{$\stackrel{\longmapsto}{0.0005}$}

Figure 3. Neighbour Joining analysis of a Turkish BoHV-4 isolate (K .339)

Şekil 3. Türkiye'den izole edilen BoHV-4 saha suşunun (K339) filogenetik analizi

\section{Discussion and Conclusion}

In this study, $29.1 \%$ of the vaginal discharge samples from cows with postpartum metritis were found to be BoHV-4 DNA-positive. The rate of positivity in tested vaginal discharges was highest for gB-PCR (29.1\%), which was followed by IFA $(21.8 \%)$ and VI techniques (12.7\%). Overall seroprevalence of BoHV-4 is estimated as $69.6 \%$. Of cattle with metritis and healthy animals housed together with the cattle with metritis in the postpartum period, approximately 70 percent were seropositive for antibodies versus BoHV-4. Although the prevalence of antibodies to BoHV-4 in healthy animals is generally high, the evidence of BoHV-4 related clinical signs have not been detected. These antibodies in healthy cattle were concluded to be formed before the time of sampling. However, due to the highest rates of seropositive animals BoHV-4 infection have been circulated subclinically in this herd at a relatively high level.

The pathogenesis of BoHV-4 infection was questioned due to the isolation of BoHV-4 from healthy individuals, and from cattle with a wide variety of clinical signs $(12,19)$. The virus has been isolated from cattle with genital problems (metritis, mastitis) as well as healthy animals. Several studies established a strong relationship between BoHV-4 antibody and fertility problems encountered $(4,12,18)$. In contrast to studies reported by Fabian et al (6), Frazier et al (7) and Monge et al (12) reported that BoHV-4-related post-partum metritis cases are an important problem in the United States and Spain, respectively (7). In this study were pointed that there is an interaction between the BoHV-4 infection and postpartum metritis. However, it should be remembered that other factors (viruses, bacteria, etc.) that might have influences on the high rate of metritis cases. In this study, we mainly planned to investigate the presence of BoHV-4 in cattle with metritis. BVDV was not investigated in vaginal discharge samples, because, cattle has been vaccinated with a combined conventional vaccine for along time. But, we tested all vaginal discharge samples for BoHV-1, because the sampled animals might be latently infected or reinfected in spite of vaccination for BoHV-1 in this herd. No positive samples for BoHV-1 were detected using PCR and IFA techniques (unpublished data).

Virological examination of BoHV-4 infection was done using three different techniques. Positivity rates of these techniques, namely gB PCR, VI and IFA were $29.1 \%, 12.7 \%$ and $21.8 \%$, respectively. It is noted that all of the samples detected as positive with either VI or IFA for BoHV-4 were also positive with gB PCR. Similarly, Wellenberg et al (20) reported that the $\mathrm{gB}$ primer was sensitive enough to detect only 2 to 10 BoHV-4 DNA molecules in a sample and that the sensitivity of PCR method with $\mathrm{gB}$ primers and virus isolation were estimated as $93 \%$ and $61 \%$, respectively. It is known that the $\mathrm{gB}$ primer has been used because of the conserved nature of this gene (20). In addition the $\mathrm{gB}$ is essential in the BoHV-4 infection (9) and constitutes an important component of the virion particle (10). Overall thirteen of 16 animals infected with BoHV-4 were seropositive, only 3 animals were found seronegative (Table 2). These cows were not re-examined for seroconversion. Our opinion is that, these cows $(n=3)$ sampled after first calving had primary infection. Otherwise, it is possible that the seropositivity detected in the others is associated with the reactivation of latent infection because of their age and lasting circulation of the infection.

The nucleotide sequence of a field isolate (K-339) had $99 \%$ percent nucleotide identity with sequence of 5 various BoHV-4 isolates (accession numbers AJ617688, Z15044, AJ609274, AJ617687, AF318573) identified as European strain like Movar 33, in GenBank and DN-599 of which the sequence analysis was performed in this study (Table 2). The Neighbourhood Joining analysis indicated that isolate $\mathrm{K}-339$ is genetically more close to the viruses reported from UK rather than those from mainland Europe (Figure 3). The identity matrix of the sequences between Turkish and UK isolates was recorded as 99.4\%. On the other hand, DN-599 (e.g reference strain of BoHV-4) was found in a separate cluster with two BoHV-4 viruses from mainland Europe.

Data shown that BoHV-4 is common and one of the possible aetiological agent causes the metritis in sampled animals in the post partum period. In this study, the molecular characterization of BoHV-4 has reported for the first time in Turkey. According to the results, the Turkish BoHV-4 isolates are closely related to strains from UK, but relatively different from mainland Europe. Further studies need to be planned based on the 
investigation of other agents causing metritis, and also BoHV-4 and the isolation and molecular characterisation of the BoHV-4 field strains from cows with clinical outcome except metritis.

\section{Acknowledgements}

We thank to Prof.Dr.Aykut Ozkul for all helps and The Scientific Research Project Directorship of Ankara University (Project no. 20040810 068) for financial support.

\section{References}

1. Bartha A, Juhasz M, Liebermann H (1966): Isolation of a bovine herpesvirus from calves with respiratory disease and keratoconjunctivitis. Acta Vet Acad Sci Hung, 16, 357-358.

2. Belak S, Palfi V (1974): Characterization of a herpesvirus isolated from spontaneously degenerated bovine kidney cell culture. Acta Vet Acad Sci Hung, 24, 249-253.

3. Bilge-Dagalp S, Demir B, Güngör E, Alkan F (2007): The seroprevalence of bovine herpesvirus type 4 (BoHV-4) infection with reproductive disorders. Rev Med Vet, 158, 201-205.

4. Czaplicki G, Thiry E (1998): An association exists between bovine herpesvirus 4 seropositivity and abortion in cows. Prev Vet Med, 33, 235-240.

5. Dubuisson J, Thiry E, Bublot M, Thomas I, Van Bressem MF, Coignoil F, Pastoret PP (1989): Experimental infection of bulls with a genital isolate of bovine herpesvirus 4 and reactivation of latent virus with dexamethasone. Vet Microbiol, 21, 97-114.

6. Fabian K, Makrai L, Sachse K, Szeredi L, Egyed L (2008): An investigation of the aetiological role of bovine herpesvirus 4 in bovine endometritis. Vet J, 177, 289-292.

7. Frazier K, Baldwin C, Pence M, West J, Bernard J, Liggett A, Miller D, Hines M (2002): Seroprevalence and comparison of isolates of endometriotropic bovine herpesvirus-4. J Vet Diag Invest, 14, 457-462.

8. Goltz M, Broll H, Mankertz A, Weigelt W, Ludwig H, Buhk HJ, Borchers K (1994): Glycoprotein B of bovine herpesvirus type 4: Its phylogenetic relationship to $g B$ equivalents of the herpesviruses. Virus Genes, 9, 53-59.

9. Little SP, Jofre JT, Courtney RJ, Schaffer PA (1981): A virion-associated glycoprotein essential for infectivity of herpes simplex virus type 1. Virology, 115, 149-160.

10. Lomonte P, Filee P, Lyaku JR, Bublot M, Pastoret PP, Thiry E (1997): Glycoprotein B of bovine herpes- virus 4 is a major component of the virion, unlike that of two other gammaherpesviruses, Epstein Barr virus and murine gammaherpesvirus 68. J Virol, 71, 3332-3335.
11. Miyano H, Haritani M, Sentsui H, Tsuboi T, Tanimura N, Kimura KK, Kobayashi M, Obara N, Akimoto Y (2004): Mammary lesions associated with bovine herpesvirus Type 4 in a cow with clinical mastitis. J Vet Med Sci, 66, 457-460.

12. Monge A, Elvira L, Gonzalez JV, Astiz S, Wellenberg GJ (2006): Bovine herpesvirus 4-associated postpartum metritis in a Spanish dairy herd. Res Vet Sci, 1, 120-125.

13. Nettleton PF, Herring JA, Herring AJ (1983): Evaluation of an immunofluorescent test for the rapid diagnosis of field infections bovine rhinotracheitis. Vet Rec, 112, 298-300.

14. Nikolin VM, Donofrio G, Milosevic B, Taddei S, Radosavljevic V, Milicevic V (2007): First Serbian isolates of bovine herpesvirus 4 (BoHV 4) from a herd with a history of postpartum metritis. New Microbiol, 30, 5357.

15. Osorio FA, Reed DE (1983): Experimental inoculation of cattle with BoHV-4 evidence for a lymphoid associated persistent infection. Am J Vet Res, 44, 975-980.

16. Roizman B, Desroisers RC, Fleckenstein B, Lopez C, Minson AC, Studdert MJ (1992): The family herpesviridae: an update. Arch Virol, 123, 425-449.

17. Sambrook J, Fritsch EF, Maniatis T (1989): Molecular cloning. In: Sambrook J, Fritsch EF, Maniatis T, Eds. A Laboratory Manual. Cold Spring Harbor Laboratory Press, New York.

18. Wellemans G, Van Opdenbosch E, Mammerickx M (1986): Experimental inoculation of bovine herpesvirus 4 (strain LVR 140) in pregnant and non-pregnant cows. Ann Rech Vet, 17, 89-94.

19. Wellenberg GJ, Van Der Poel WHM, Van Der Vorst TJK, Van Valkengoed PHR, Schuhken YH, Wagenaar F, Van Oirschot JT (2000): BoHV-4 in bovine clinical mastitis. Vet Rec, 147, 222-225.

20. Wellenberg GJ, Verstraten ERAM, Belak S, Verschuren FAM, Rijsewijk R, Peshev R, Van Oirschot JT (2001): Detection of bovine herpes virus 4 glycoprotein $B$ and thymidine kinase DNA by PCR assays in bovine milk. J Virol Methods, 97, 101-112.

Geliş tarihi: 13.01.2009 / Kabul tarihi: 17.07.2009

Adress for correspondence
Doç.Dr.Seval Bilge-Dağalp
Ankara Üniversitesi Veteriner Fakültesi
Viroloji Anabilim Dall, Dışkapı, Ankara,
Tel: +90 $3123170315 / 447$, Faks: +90 3123164472
E-mail: sevalbilge@hotmail.com

Adress for correspondence

Doç.Dr.Seval Bilge-Dă̆alp

Ankara Üniversitesi Veteriner Fakültes

Tel: +90 $3123170315 / 447$, Faks: +90 3123164472

E-mail:sevalbilge@hotmail.com 